https://ejournal.uniska-kediri.ac.id/index.php/PROFICIENCY

\title{
THE TEACHING OF SPEAKING BY USING WEBTOON AT CHOICE ENGLISH COURSE PARE KEDIRI
}

\author{
By: Moh. Syaiful Adlim
}

\begin{abstract}
Webtoon is a type of digital comic or comic application. The research aimed to find out the teaching of speaking by using Webtoon at Choice English course Pare Kediri. The design used is descriptive qualitative. The data collection method were interview, observation, documentation, questionnaire and filed note. The result of this research showed that the teaching of speaking by using Webtoon at Choice English course Pare Kediri had been supported by curriculum but it had not been documented, it also had been supported by syllabus and lesson plan, the material was from Webtoon, and the techniques used were retelling story and role play. The evaluation of this program was taken on Saturday at the last week by calling the students one by one to deliver a speech based on the tittle they took in the lottery. The students' response was known that students were very active, happy and they enjoyed the program. The result of the students' after getting this program was there were $8(40 \%)$ students got A (Excellent), $11(55 \%)$ students that B (Very Good), 1 (5 \%) student got C (Good), and no student got C (Average) or D (Poor).
\end{abstract}

Keywords: English comics, speaking, teaching speaking, Webtoon

\section{INTRODUCTION}

The main objective of studying English is to communicate effectively and efficiently by using the international language. One of the skills that must be mastered in studying English is speaking skill. Speaking is the ability to speak fluently presupposes not only knowledge of language features but also the ability to process information of language on the spot (Hammer, 2001:269). Fulcher (2003:23) states that speech is about making choices. Speakers have to choose how to get good interaction in expressing themselves in global social relationship through speech.
Brown (2000:217) writes that speaking skill required two aspects, namely linguistic and non-linguistic aspect. Linguistic aspect is the main requirement that the English learner should possess in order to speak well. Which involves pronunciation, vocabulary, fluency, structure and comprehension. While non-linguistic aspect is an aspect to support learners to achieve a success in acquiring speaking skill. This aspect involves personality dimensions, such as selfesteem, self concept and extroversion. Mcdonough and Shaw (2013:157) write that there are some reasons for speaking involved expressing idea and opinions, 
expressing a wish or desire to do something, negotiating or solving a particular problem, or establishing or maintaining social relationship and friendship. It can be concluded that speaking is the most important skill that should be learnt, but many people feel very difficult to learn English.

The difficulties in learning speaking can be caused from internal and external factors. Internal factors is from the learner itself, there are several discussions about problems that come from body of the students their self. The problems are commonly become obstacles in teaching speaking. Some of them are native language, motivation and concern for good speaking. The native language is the most influential factor affecting a learner's speaking. Brown, (2000:284) states, "If you are familiar with the sound system of learner's native language, you will be better able to diagnose student difficulties. Many L1-L2 carryovers can be overcome through a focused awareness and effort on the learner's part."

By the statement it concludes that mother language of students will be a problem in teaching speaking if the teacher cannot understand the fact and decided a way to solve the condition moreover if the linguistic aspect of the native language students have is really different with target language. Motivation and concern for good speaking, some learners are not particularly concerned about their speaking, while others are. Brown, (2000:285) says that motivation and concern are high, and then the necessary effort will be expended in pursuit of goals. It means that motivation is very important in teaching speaking. The teacher does not have other choice expect try to wake students' motivation. Motivation means a cluster of factor that 'energizes' the behavior and gives it 'direction'. It can be concluded that motivation is term used to describe what energize a person and what directs his activity, and energy and direction are the center of motivation. The problem is that motivation is a very complex thing and how to build motivation from the students. Moreover, each student has his own characteristic so it needs many strategies and approach to make up the motivation.

External Problem, the effectiveness of teaching speaking does not only come from internal aspects of the students but also influenced by external factors. The completeness understanding of problem in teaching speaking should be known by the teacher. The factor is an institutional context that puts English as second or foreign language in a nation. The context in which the language is learnt is still considerable relevance to kind of English a nation will want and need to study, and the skills they will need to acquire.

In the external problem, teaching speaking has challenge to make suitable classroom hours, because usually in the junior or senior high school English lesson only four hour a week, so they do limited time and they do not maximize in their ability in English, they do not have the maximal time to practice in the outside of classroom 
https://ejournal.uniska-kediri.ac.id/index.php/PROFICIENCY

because the teacher should teach suitable with the syllabus from the government, remembering that there is final examination from the government. They do not have time to practice outside the classroom because they do not have suitable partner to speak in English and the fact, they 'speak in their native language.

Indonesian people also feel difficult in learning speaking English skill, not only because of internal factors but also external factors. English in Indonesia is not as the native language that will be used by the people sooner after being delivered. Ellis (1994:74) as cited in Nadiroh (2011:9) said that English is as a foreign language that will be used after some years later. Consequently, the people need extra energy and time to master the language. Predictably, there will be some constraints faced before they easily conduct a communication in English. This is why the Indonesian government chooses English as the first foreign language to be taught in schools (Ramelan, 1992:3) as cited in Fauzana (2016:1).

Speaking English in Indonesia can be learnt in formal and informal class. Formal education can be found from kinder garden, elementary school, junior high school and senior high school. Formal school, teacher has to prepare learning instrument administration based on the ministry of education in Indonesia. Nonformal education is an any organized educational activity outside the established formal system. It can be found from out of school, such as course, private education at home, like home schooling and private course. Teacher provides materials based on the necessary of students. Based on UU Sisdiknas in UU No 20 year of 2003 Part 5 Non-formal Education Pasal 26, course and coaching are hold for society who need preparations of knowledge, skill, life qualification, and the attitude of self-development, developing career, work, business independent, and continue to get higher education. Actually, the existence of non-formal education can support learning of formal education. Non-formal education here is a course, even though at course in non-formal education, learning instrument must be prepared, but little bit different from formal education, the composing learning instrument is done by intern team. At course provides many kinds of learning, and the learning itself based on the necessary by students.

From the explanation above one of well known non formal education in Indonesia to study English is at "Kampung Inggris" in Kediri, exactly in Pare. Pare is one of the sections at Kediri city that famous with its English courses so that's why Pare is famous to call "Kampung Inggris". There are many English courses in Pare. Some of them are Basic English Course (BEC), Elfast, Kresna, Choice, Global English, Access, Mahesa, Marveloues, Webster and Mr. Bob English Club. Most of all English Courses offer Speaking Class by using different ways and different interesting media.

One of the courses that teaches speaking by using interesting media is Choice English Course. Choice English Course will 
https://ejournal.uniska-kediri.ac.id/index.php/PROFICIENCY

be the object of research about speaking program. The unique of Choice English Course is this course uses Webtoon English comic application to teach speaking in their speaking class. Choosing Webtoon as the media for teaching speaking at Choice English Course is not without any reason. It is based on the tutor's observation that English comic is liked by the students because they like stories. It is also an appropriate media for the students at their age because English comic application is more simple for the students than English comic book. According to Gerlach and Elly (1980: 245) as cited in Nadiroh (2011:24), to select the appropriate media, the teacher must consider the characteristics of the students, which directly related to the learning process such as verbal abilities, visual and audio perception skills.

Webtoon is a type of digital comic or comic application. The comic in webtoon is almost like the ordinary comic that is to express ideas by images, combined with text or other visual information. According to McCloud (1993:20), comics are juxtaposed pictorial and other images in deliberate sequence, intended to convey information and/or to produce an aesthetic response in the viewer. There are three things that distinguish webtoon with ordinary comics. Each chapter or episode is published on a long vertical strip making it easier to read on a smartphone or computer, it is more colorful and not black and white, and it also has some animations and music playing in each chapter making the reader more interested. The reason of choosing the tittle as thesis is to find out the teaching of speaking by using Webtoon at Choice English Course Pare Kediri. This research intends to answer the following questions:

1. How is the teaching of speaking by using Webtoon at Choice English course Pare Kediri (in the term of the curriculum, syllabus, lesson plan, material, and technique)?

2. How is the process of the teaching of speaking by using Webtoon at Choice English Course Pare Kediri?

3. How is the evaluation of the teaching of speaking by using Webtoon at Choice English Course Pare Kediri?

4. How is the response of the students toward the teaching of speaking by using Webtoon at Choice English Course Pare Kediri?

5. How is the result of the students' speaking ability after being taught using Webtoon at Choice English Course Pare Kediri?

\section{METHOD}

The design of this research was descriptive qualitative. It was conducted at Choice English Course Pare Kediri. It was located on Pancawarna street Kampung Inggris Pare, Kediri 64212. In this research, the researcher made instruments to solve the problems. This research applied natural setting, and treatment was not applied here. The researcher did observation, interview, questionnaire, documentation and field note.

The observation included observing the students' activity and 
steps of teaching from starting the program until it was done. The class observations were conducted on $12^{\text {th }}$ of March $2018-25^{\text {th }}$ of March 2018. This observation used procedure as follow:

a. Joining the English Speaking class of one month program at Choice English Course Pare to observe the teaching learning process.

b. Giving check-list sign $(\sqrt{ })$ in the column that suitable with the data observed by giving an answer Yes/No. Yes, if the data collected are found, No, if the data collected are not found.

c. Giving a comment that the activity in the class was appropriate or not from the aspect of the criteria set.

The interview was conducted with the director, the tutor, and the students of speaking class. This interview guide summarized questions about the focuses and sub focus of this research. There were 24 questions used in this case. The $1^{\text {st }}$ question untill the $10^{\text {th }}$ question was for the first focus, that was the teaching of speaking by using Webtoon at Choice English course Pare Kediri (in the term of the curriculum, syllabus, lesson plan, material, and technique). The $11^{\text {th }}$ question until the $15^{\text {th }}$ question was for the second focus, It was about the process of the teaching of speaking by using Webtoon at Choice English Course Pare Kediri. The $16^{\text {th }}$ question until the $22^{\text {nd }}$ question was for the third focus, it was about the evaluation of the teaching of speaking by using Webtoon at Choice English Course Pare Kediri.
The $23^{\text {rd }}$ question was for the fourth focus, it was about the response of the students toward the teaching of speaking by using Webtoon at Choice English Course Pare Kediri. The $24^{\text {th }}$ question was for the fifth focus, it was about the result of the students' ability after being taught using Webtoon at Choice English Course Pare Kediri. This interview used procedure as follows:

a. Visiting the owner and asking a permission to have interview with the tutor, the student, and the owner himself.

b. Asking the owner some questions about the history of the Choice English Course, the teaching of speaking by using Webtoon (in the term of the curriculum, syllabus, lesson plan, material, and technique), the process and the evaluation of the teaching of speaking by using Webtoon at Choice English Course Pare, the response of the students toward the teaching of speaking by using Webtoon, and also the result of the students' speaking ability after being taught using Webtoon at Choice English Course Pare Kediri.

c. Asking the tutor some questions prepared about the teaching of speaking by using Webtoon (in the term of the curriculum, syllabus, lesson plan, material, and technique), the process and the evaluation of the teaching of speaking by using Webtoon at Choice English Course Pare, the response of the students toward the teaching of speaking by using Webtoon, and also the result of the students' speaking ability after being taught using Webtoon at 
https://ejournal.uniska-kediri.ac.id/index.php/PROFICIENCY

Choice English Course Pare Kediri.

d. Asked the student about the material and technique which was used by the tutor in the teaching of speaking by using Webtoon, the process and the evaluation of the teaching of speaking by using Webtoon at Choice English Course Pare, and the response of the students toward the teaching of speaking by using Webtoon.

Questionnaire was to collect the data about the students' perception. In this research, the questionnaires which were given to the subjects had twenty (20) questions with five (5) option items in the form of table. The option items were: always, often, sometimes, seldom, and never which indicated the degree of respondent. The questionnaire used procedure as follows:

a. Asking permission to give the questionnaire to the students of speaking class in one month program at Choice English course.

b. Waiting for the students to answer the questions based on their opinions.

c. Collecting the questionnaire which have been answered by the students.

Then, the researcher collected the documentation need in research. The document in this research was consisting of the syllabus, lesson plan, attendance list of speaking class of one month program, the score of the students' speaking, and the photo of teaching speaking process. The documentation used procedure as follows: a. Asking permission to look the document that Choice English Course has.

b. Taking documentation with camera phone for the document that could not be copied and taking the document that could be copied or asking the soft file.

Field notes were used in this case either interviewing or observing. The researcher monitored the whole phenomenon which happened during teaching learning in the classroom by recording and making notes in the form of outlines during teaching and learning. After that, the researcher changed the outlines which were made in the form of complete field note. The field note used procedure as follow:

a. Checking the syllabus and lesson plan.

b. Writing the action that was not written in the lesson plan.

c. Giving a comment that the activity in the class was appropriate or not from the aspect of the criteria set.

The data analysis in this research was based on three concurrent flows of activities, they were: data reduction, data display, and verification. Data reduction was used to classify, direct, and organize the data obtained from interviews, observations, and documentations. Data display was used to present the data in the form of brief description, charts, relationship between categories, and so on. Verification was used to present preliminary conclusion which is still tentative and needed evidence to support strong data collection. 
https://ejournal.uniska-kediri.ac.id/index.php/PROFICIENCY

\section{RESULT}

Based on the interview and documentation about result, it could be found that the learning outcomes of the students during the program in the teaching of speaking by using Webtoon at Choice English course was there were $8(40 \%)$ students that got A (Excellent), 11 (55\%) students that got B (Very Good) and $1(5 \%)$ student that got $\mathrm{C}$ (Good). It showed that the speaking ability of the students was good.

This was appropriate with the theory from Wright (2008) that the result was something that is obtained from a process. In this section, the intended results are overall values in rubric. With the data on the rubric, it can be seen learning outcomes of students on a material that has been delivered.

It can be said that the result was good because only 1 (5\%) student got C (Good), no student got D (AVERAGE) and E (POOR) and that was good.

The response of the students toward the teaching of speaking by using Webtoon at Choice English Course Pare Kediri

Based on the observation, questionnaire and interview can be found that the response of the students toward the teaching of speaking by using Webtoon at Choice English Course Pare Kediri was the students were very active, happy and enjoyed the teaching learning porcess. The students enjoyed the teaching learning process because they felt interesting and happy because the teaching learning process and also the story in Webtoon were not boring. The students also felt satisfied because they did not only study speaking but also they got many vocabularies from the story.

The result of the students' ability after being taught using Webtoon at Choice English Course Pare Kediri

The result of the students' ability after being taught using Webtoon at Choice English Course Pare Kediri was was good. The results of the students was good because 8 students got A score (excellent), 11 students got B score (very good) and 1 student got C score (good). No student got D score (average) or E score (poor).

\section{CONCLUSION AND SUGGESTION \\ Conclusion}

Based on the result that the researcher got, this research could be concluded as:

1. The teaching of speaking by using Webtoon at Choice English course Pare Kediri (in the term of the curriculum, syllabus, lesson plan, material, and technique), was good. Because just one point that not appropriate that was curriculum, and the other was appropriate.

2. The process of the teaching of speaking by using Webtoon at Choice English Course Pare Kediri (in the terms of pre teaching, teaching, and post teaching) was very good, because all of the points were appropriate.

3. The evaluation of the teaching of speaking by using Webtoon at Choice English Course Pare 
https://ejournal.uniska-kediri.ac.id/index.php/PROFICIENCY

Kediri was very good because all of the points were appropriate.

4. The response of the students toward the teaching of speaking by using Webtoon at Choice English Course Pare Kediri was very good because the students were very active, happy and they enjoyed the teaching learning process.

5. The result of the students' ability after being taught using Webtoon at Choice English Course Pare Kediri was good because there wase only 1 student got $\mathrm{C}$ score (good), and there were 8 students get A score (excellent), 11 students get B score (very good) and no student got D score (average) or E score (poor).

6. Based on the findings above the teaching of speaking by using Webtoon at Choice English Course Pare Kediri was good because just one point that was not appropriate and the others were maximal and appropriate.

\section{Suggestion}

The suggestions based on the research which had been done are stated as follow:

1. For the tutor, it will be better to use more techniques to make the students more interested in joining the class.

2. For the owner, it is better to have a curriculum because it can make the teaching learning process run well under the guidance and responsibility of the course.

3. Finally, for next researchers are recommended to explore further about the teaching of speaking by using Webtoon in other course. This research can be used as a reference for the future researchers who want to explore about the teaching of speaking by using Webtoon.

\section{REFERENCES}

Brown, D. H. 2000. Principles of Language Learning and Teaching. New York: Addision Wesley Longman,inc.

Fauzana, V. 2016. The Effects of Using Picture Series on The Writing Procedure Texts of The Second Year Students of Mts Darul Funun ElAbbasiyah Kabupaten 50 Kota. University of Riau.

Fauziati, E. 2002. Teaching of English As A Foreign Language. Surakarta:
Muhammadiyah University Press.

Fulcher, G, 2003. Testing Second Language Speaking. London: Longman.

Harmer, J. 2001. The Practice of English Language Teaching. London and New York: Longman Publishing.

Mccloud, S. 1993. Understanding Comics:The Invisible Art. New York: Kitchen Sink Press. 
https://ejournal.uniska-kediri.ac.id/index.php/PROFICIENCY

MCdonough \& Shaw. 2013. Materials And Methods In Elt, London: Wiley-Blackwell.

Nadiroh, U. 2011. The Use of English Comic to improve the ability in retelling story of the second year students of SMAN 1 Kandat Kediri. Islamic University of Kadiri.
Wadler. 2007. Reflective teaching in second language classrooms. New York: Cambridge University Press.

Wright, J. R. 2008. Educational Assessment: Tests and Measurements in the Age of Accountability. New York: SAGE Publications, Inc. 